\title{
Causes of long-term changes in Aegean sea deep water
}

\section{Roberta BOSCOLO ${ }^{a *}$, Harry BRYDEN ${ }^{b}$}

${ }^{a}$ Instituto de Investigación Mariñas, CSIC, Eduardo Cabello 6, 36208 Vigo, Spain

${ }^{\text {b }}$ Southampton Oceanography Centre, Southampton SO14 3ZH, United Kingdom

Received 10 April 2001; revised 23 July 2001; accepted 26 July 2001

\begin{abstract}
Recent observations of newly formed deep water in the Aegean sea prompts this analysis of whether such deep water could be formed locally by the combination of an increase in net evaporation and wintertime water mass transformation. River diversion projects in Russia and Egypt since the 1950s have effectively increased the amount of net evaporation over the eastern Mediterranean basin. Historical profiles show that low salinity intermediate waters separated the deep and upper waters in the Aegean in 1961-1962. Within a simple mixed layer model, imposing a small net evaporation of $10 \mathrm{~cm} \cdot \mathrm{yr}^{-1}$ on the observed hydrographic conditions in March 1962 results in the gradual erosion of the low salinity intermediate waters. After 25 years, the low salinity intermediate waters are absent in agreement with observations made in September 1987. Continuing to force the model with the small net evaporation and with monthly heat and freshwater exchange anomalies from March 1987, new deep water could have been formed as early as March 1988. In the model, major deep water formation events occurred during the severe winters of 1991-1992 and 1992-1993 resulting in the formation of saltier and notably colder deep waters. The effective increase in net evaporation slowly increases the salinity and decreases the stratification in the Aegean sea until a severe winter leads to deep convection and new bottom water formation. (C) 2001 Ifremer/CNRS/IRD/Éditions scientifiques et médicales Elsevier SAS
\end{abstract}

Résumé - Causes des changements à long terme de l'eau profonde de la mer Égée. Des observations récentes de l'eau profonde nouvellement formée en mer Égée permettent de déterminer si son origine est locale, suite à l'action combinée de l'évaporation nette et de la transformation hivernale de la masse d'eau. Les détournements des cours de rivières en Russie et en Égypte depuis les années cinquante ont en effet accru l'évaporation nette dans le bassin oriental de la Méditerranée. Des profils historiques montrent que les eaux intermédiaires de basse salinité séparent les masses d'eaux profonde et supérieure en mer Égée depuis les années 1961-1962. L'utilisation d'un modèle simple de couche de mélange où une évaporation nette de $10 \mathrm{~cm} \cdot \mathrm{an}^{-1}$ a été appliquée aux conditions hydrologiques observées en mars 1962 conduit à une diminution graduelle des eaux intermédiaires de basse salinité. Après 25 ans, ces eaux intermédiaires de basse salinité disparaissent, ce qui est en accord avec les observations réalisées en septembre 1987. Si l'on continue le forçage du modèle avec la même évaporation et en tenant compte des anomalies mensuelles des échanges de chaleur et d'eau douce depuis mars 1987, l'eau profonde «nouvelle » pourrait avoir été formée dès mars 1988. Avec ce modèle, des événements majeurs assurant la formation de l'eau profonde apparaissent. Durant les hivers rigoureux de 1991-1992 et de 1992-1993, des eaux profondes plus salées et notablement plus froides furent ainsi formées. L'accroissement de l'évaporation nette accroît progressivement la salinité et réduit la stratification en mer Égée jusqu'à ce qu'un hiver rigoureux entraîne une convection profonde et la formation d'une nouvelle eau de fond. () 2001 Ifremer/CNRS/IRD/Éditions scientifiques et médicales Elsevier SAS

air-sea interaction / deep water formation / Mediterranean circulation / hydrological budget / Aegean sea échanges océan-atmosphère / formation d'eau profonde / circulation en Méditerranée / budget hydrologique / mer Égée

*Correspondence and reprints: fax: +34 986292762.

E-mail address: rbos@iim.csic.es (R. Boscolo). 


\section{INTRODUCTION}

The Mediterranean is getting saltier. The salinity of western Mediterranean deep water formed in late winter in the Gulf of Lions is increasing at a rate of 0.007 per decade Lacombe et al. 1984: Leaman and Schott. 1991. Bohling and Bryden. 1992. There is some evidence that Levantine Intermediate Water is also increasing in salinity Rohling and Bryden. 1992). Most dramatically, new deep water has been observed to form in the Aegean sea between 1987 and 1995 with a salinity 0.12 higher than previous deep water salinities observed in the eastern Mediterranean during this century Roether et al. 1996. Klein et al. 1999). Rohling and Bryden (1992) argued that increasing Mediterranean salinity should be expected as a result of the change in the water budget for the Mediterranean basin following the diversion of the Nile and Russian rivers for irrigation. They predicted, on the basis of hydraulic control arguments for the exchange across the Gibraltar sill, that the Mediterranean salinity would eventually increase by 0.13 as a result of the effective $10 \%$ increase in net evaporation $(E=e-p-r$, evaporation minus precipitation minus river runoff) due to river diversion. It is useful to understand how a basin becomes saltier over time by examining the pattern of salinity increase within the Mediterranean.

We argue here that the change in water budget has been locally felt first in the Aegean sea where the effective increase in net evaporation gradually erodes the low salinity intermediate waters, called Transition Mediterranean Water (TMW) by Wheocharis et al_ (1999a). After about 25 years, the low salinity intermediate waters are gone so that during severe winters convection can penetrate to great depth and new deep water can be formed at a higher salinity. The large volume of recently formed dense, deep water then spills over the sills connecting the Aegean sea to the eastern Mediterranean basin and begins to fill the deep eastern Mediterranean. As the dense water flows over the sills, lower salinity intermediate waters appear to flow back into the Aegean to replace the dense waters so that deep water formation is turned off and the cycle starts over.

\section{BACKGROUND}

Dielsen (1912) suggested that deep water might be formed in the Aegean sea but the first comprehensive

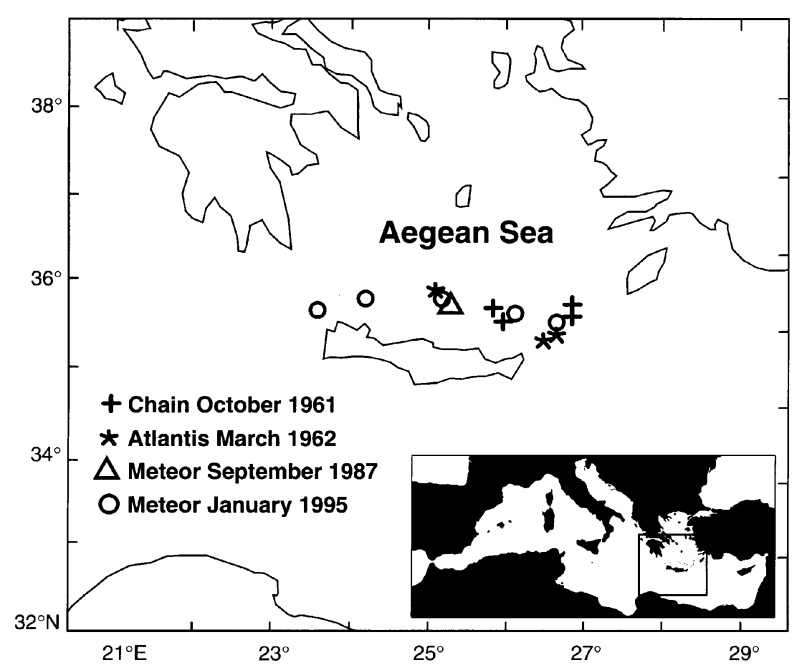

Figure 1. Location of deep stations in the Aegean sea used in the analysis. Symbols denote the different surveys in 1961, 1962, 1987 and 1995.

survey of the eastern Mediterranean identified the primary source for eastern Mediterranean deep waters to be the Adriatic (Pollak, 1951). In an experiment to examine wintertime water mass conversion in the Aegean sea (figure - Charnock and Miller made pre-winter hydrographic stations in October 1961 aboard RV Chain and post-winter stations in March 1962 aboard RV Atlantis II (Miller et al. 1970). In 1961-1962, the deep water in the Aegean had a potential temperature of $14.15^{\circ} \mathrm{C}$ and salinity of 38.95 with a potential density anomaly of $29.25 \mathrm{~kg} \cdot \mathrm{m}^{-3}$ (figure 2a). For both the October and March profiles, the deep water is separated from the surface waters above $500 \mathrm{~m}$ depth by lower salinity (38.75) TMW. Above this intermediate water, the water column is stratified primarily by temperature and the upper waters have salinity close to that of the deep water. Below the intermediate water salinity minimum, the deep water column is stratified primarily by salinity.

To make deep water locally with the observed deep water properties from the observed October 1961 profiles, there would need to be a heat loss of $3.9 \times 10^{9} \mathrm{~J} \cdot \mathrm{m}^{-2}$ to cool the water column to the deep water temperature of $14.15{ }^{\circ} \mathrm{C}$ and a net evaporation of $2.2 \mathrm{~m}$ to increase the salinity of the water column to the deep water value of 38.95. The heat loss is required primarily to cool the waters above $500 \mathrm{~m}$ depth while the net evaporation is primarily required to increase the salinity of the low salinity intermediate waters (TMW). In terms of overall 


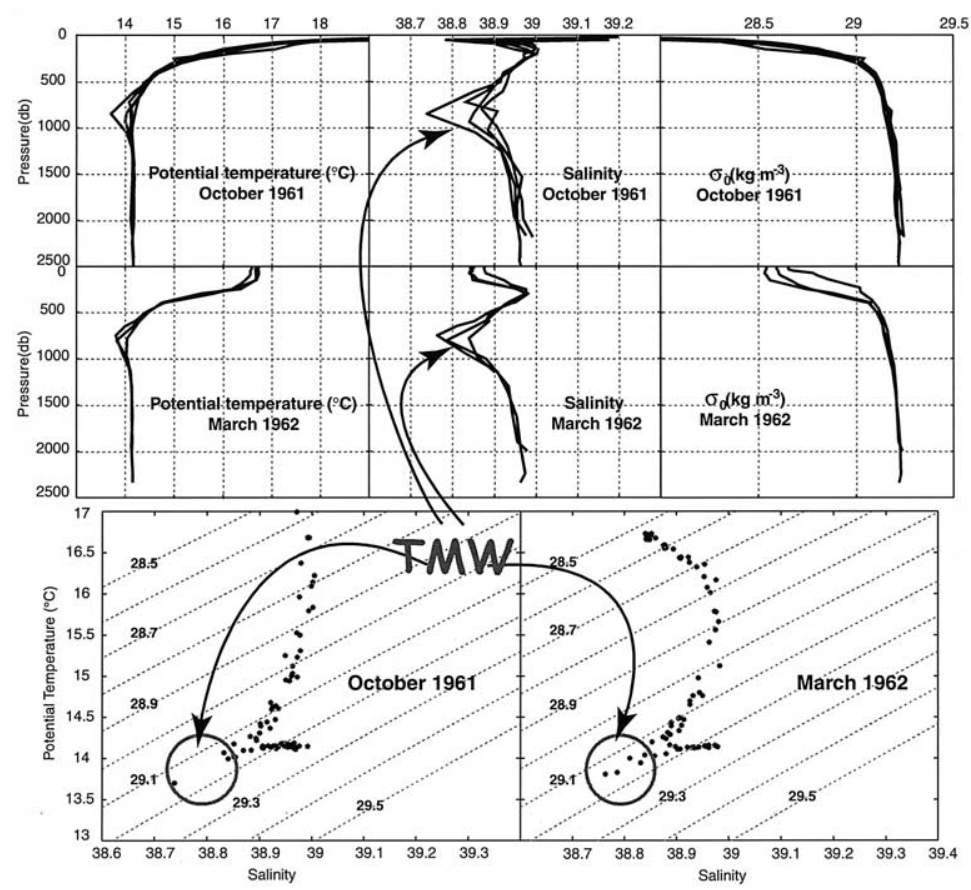

b

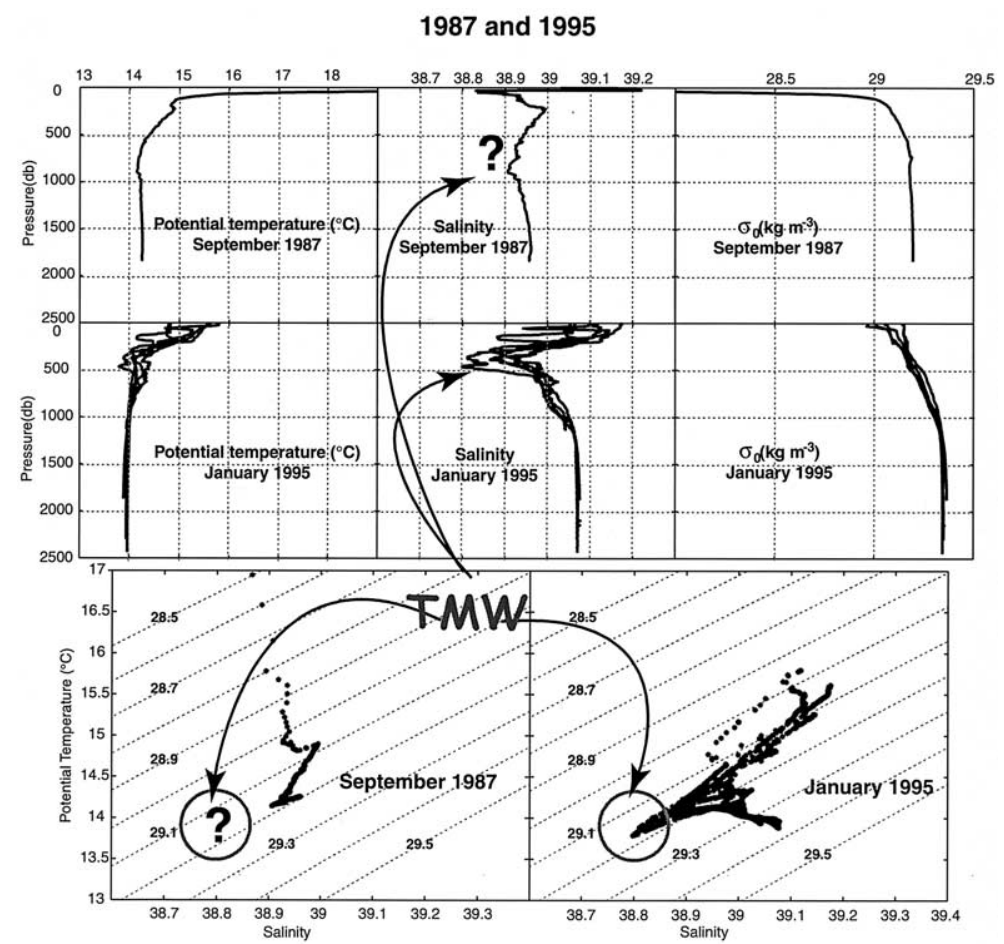

Figure 2. Potential temperature $\left({ }^{\circ} \mathrm{C}\right)$, salinity, density $\left(\mathrm{kg} \cdot \mathrm{m}^{-3}\right)$ profiles and $\theta / \mathrm{S}$ diagrams of deep Aegean stations for the (a) Chain (1961) and Atlantis II (1962) surveys, and (b) Meteor 1987 and 1995 surveys. The arrows point out the Transitional Mediterranean Water (TMW) both in the salinity profiles and in the $\theta / \mathrm{S}$ diagrams. The question marks in (b) indicate that the TMW signal was relatively weak in 1987. 
buoyancy loss, the required heat loss is about twice as large as the effect of the net evaporation in that such heat loss would increase the density by $0.055 \mathrm{~kg} \cdot \mathrm{m}^{-3}$ while the net evaporation would increase the density by $0.029 \mathrm{~kg} \cdot \mathrm{m}^{-3}$. Any buoyancy loss that increased the density of the water column by $0.095 \mathrm{~kg} \cdot \mathrm{m}^{-3}$ would of course lead to deep convection, but a different mix of heat loss and net evaporation would change the resulting deep water properties from those observed in the Aegean in 1961-1962.

Unfortunately for Miller and Charnock's experiment, the wintertime heat and freshwater losses were not great enough during the winter of 1961-1962 to form Aegean deep water (Bruce and Charnock, 1965; Miller, 1974) Based on the difference between the heat and salt contents of the water column between March 1962 and October 1961, the wintertime heat loss was in fact only $1.3 \times 10^{9} \mathrm{~J} \cdot \mathrm{m}^{-2}$, or an average of about $100 \mathrm{~W} \cdot \mathrm{m}^{-2}$ over 4.5 months between the October and March surveys, and the wintertime freshwater loss was only $0.4 \mathrm{~m}$. There was no evidence for deep water formation in the Aegean sea during the winter of 1961-1962.

There is a dearth of full-depth (>500 m) observations of temperature and salinity in the Aegean from 1962 to 1987 Zervakis et al. 2000. In September 1987, Meteor surveyed the eastern Mediterranean (Roether and SchlitEer. 1991 including full-depth profiles in the Aegean sea (foure 2b). In 1987, the deep water properties in the Aegean were effectively the same as in 1961-1962. Notably, the 1987 profiles showed a near absence of the low salinity TMW as the minimum intermediate water salinity is about 38.9 , much higher than the TMW salinity of 38.75. Comparison of September 1987 and October 1961 depth-averaged salinities shows an increase in salinity of 0.032 (table ). Due to the absence of TMW, the September 1987 conditions appear primed for wintertime deep convection: a wintertime net evaporation of only $0.5 \mathrm{~m}$ and a wintertime heat loss of $2.65 \times 10^{9} \mathrm{~J} \cdot \mathrm{m}^{-2}$ would allow local formation of the deep water observed in the winter of 1987.

In January 1995, Roether led another Meteor cruise to survey the modern deep water properties of the eastern Mediterranean. Remarkably, newly formed deep water was found in the Aegean sea and it was spilling over the connecting sills and spreading out into the deep eastern Mediterranean basins (Roether et al_ 1996). This new deep water has a potential temperature of $13.96{ }^{\circ} \mathrm{C}$, a
Table I. Deep water and depth-averaged (0-2 $000 \mathrm{~m})$ salinities in the Aegean for four different surveys. Salinities in 1961-1962 appear to be uncertain by \pm 0.02 .

\begin{tabular}{lll}
\hline Year & Deep water salinity & Depth-averaged salinity \\
\hline October 1961 & 38.955 & 38.916 \\
March 1962 & 38.976 & 38.896 \\
September 1987 & 38.960 & 38.948 \\
January 1995 & 39.071 & 39.023 \\
\hline
\end{tabular}

salinity of 39.08 , and a potential density anomaly of $29.38 \mathrm{~kg} \cdot \mathrm{m}^{-3}$ (fgure $2 b$ ). Thus, the new deep water is about $0.2{ }^{\circ} \mathrm{C}$ colder, 0.12 saltier and $0.13 \mathrm{~kg} \cdot \mathrm{m}^{-3}$ denser than the deep water of 1961-1962 or 1987. The structure of the vertical stratification, however, had returned to 1961-1962 conditions with the reappearance of low salinity intermediate waters (TMW). To form the 1995 deep waters locally, a wintertime heat loss of $1.7 \times 10^{9} \mathrm{~J} \cdot \mathrm{m}^{-2}$ would be required after January primarily to mix the waters down to $600 \mathrm{~m}$ depth and a net evaporation of $2.1 \mathrm{~m}$ would also be required primarily to erode through the TMW waters so as to form the deep water. Thus, as in 1961-1962 it does not seem feasible that deep water could be formed locally in a single winter from the observed 1995 conditions.

\section{MATERIALS AND METHODS}

To quantify the long-term effects of the rivers' runoff diversion on the deep water properties in the Aegean, we develop a simple mixed layer model where the initial profiles are taken to be the March 1962 observations of temperature and salinity (and hence density) versus depth linearly interpolated to $20-\mathrm{m}$ intervals down to $2350 \mathrm{~m}$ (Ggure $3 \mathrm{~d}$ ). In time steps of 1 year, a net evaporation of $10 \mathrm{~cm}$ is imposed on the uppermost $20-\mathrm{m}$ layer, thus representing mainly a diminution of freshwater input from rivers. Since this change in net evaporation is due to a change in river runoff, there is no change required to the heat balance. As the salinity changes in this layer the density increases. If the upper layer is denser than the layer beneath, then the layers are mixed together conserving heat and salt content. Mixing continues downward until the density stratification is stable.

The net evaporation over the eastern Mediterranean is much larger than $10 \mathrm{~cm} \cdot \mathrm{yr}^{-1}$. The Southampton Oceanography Centre (SOC) flux climatology (Josey et al., 
Model Input Profiles (March 1962)
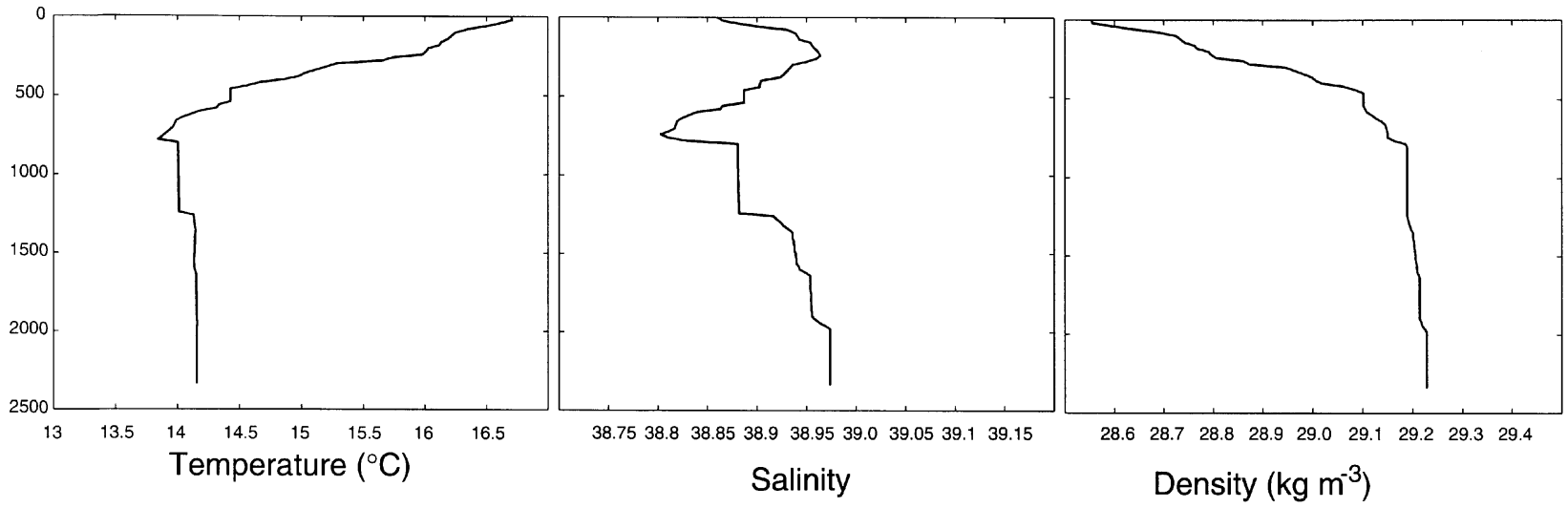

b

Model Input profiles (after initial cooling)

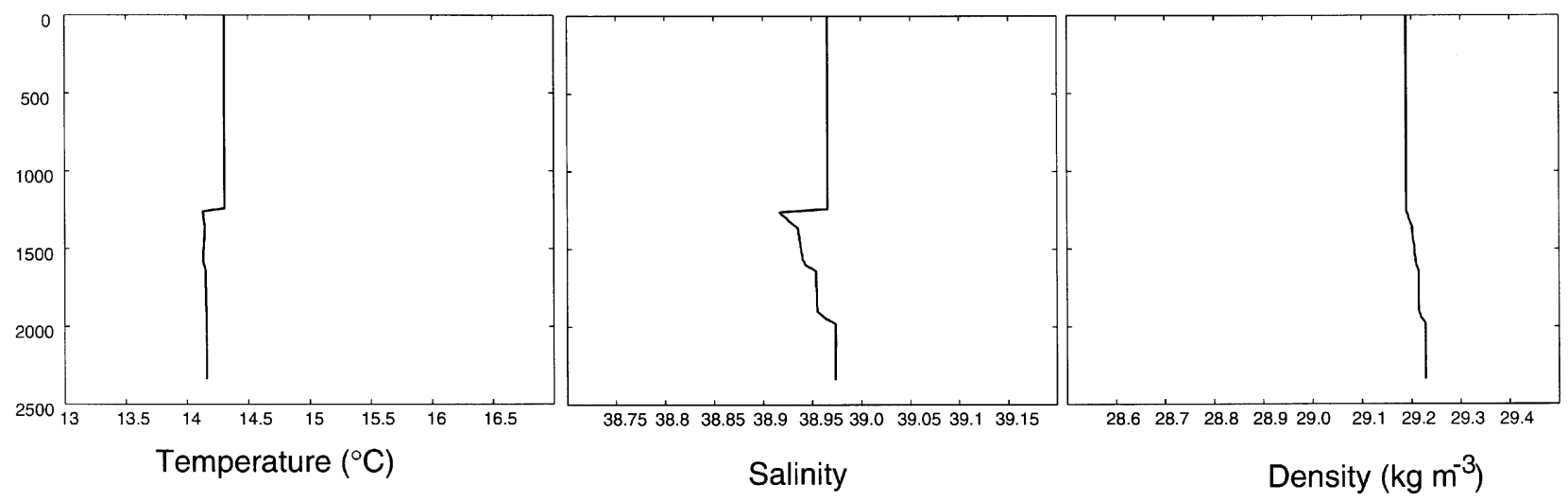

Figure 3. Potential temperature $\left({ }^{\circ} \mathrm{C}\right)$, salinity, density $\left(\mathrm{kg} \cdot \mathrm{m}^{-3}\right)$ profiles: (a) derived from March 1962 observations linearly interpolated to 20 - $\mathrm{m}$ intervals and used as initial condition in the model simulation; (b) the same as (a) but after the imposed initial cooling corresponding to a heat loss of $2.6 \times 10^{9} \mathrm{~J} \cdot \mathrm{m}^{-2}$.

1999) exhibits an $\mathrm{e}-\mathrm{p}$ over the Aegean sea of $101 \mathrm{~cm} \cdot \mathrm{yr}^{-1}$ and Bethowx (1980) estimated E to be $108 \mathrm{~cm} \cdot \mathrm{yr}^{-1}$ over the whole eastern basin. We assume that such freshwater losses are balanced by the long-term averaged circulation within the eastern Mediterranean and the Aegean so that there is no local increase in salinity over time. Rohling and Bryden (1992) estimated an effective change in net evaporation of $5 \mathrm{~cm} \cdot \mathrm{yr}^{-1}$ due to the river diversion, this value represented an average over the entire Mediterranean-Black sea basin. Because the major changes occur in the eastern parts of the basin due to irrigation projects in Egypt and Russia, the local changes in $\mathrm{E}$ over the eastern basin would be expected to be larger than average. Comparison of the 0 to $2000 \mathrm{~m}$ depth-averaged salinities in 1961 and 1962 with those for
September 1987 indicate a salinification over time between 0.032 and 0.052 , equivalent to a net evaporation between 6.3 and $10.7 \mathrm{~cm} \cdot \mathrm{yr}^{-1}$ over the 25 -year period. Thus, we settled on a reasonable value of $\mathrm{E}=10 \mathrm{~cm} \cdot \mathrm{yr}^{-1}$ for the extra net evaporation due to river diversion in the model simulations.

To neutralise the temperature stratification in order to concentrate on the effects of net evaporation on the deep convection, we removed an amount of heat equal to $2.6 \times 10^{9} \mathrm{~J} \cdot \mathrm{m}^{-2}$ from the March 1962 profiles before running the mixed layer model. This is equivalent to one extra harsh winter as the average winter (November to February) removes $1.7 \times 10^{9} \mathrm{~J} \cdot \mathrm{m}^{-2}$ heat over the Aegean sea according to the SOC climatology. Dut to the lack of 
observations, we do not know when such heat loss might have occurred. It could have happened slowly over the period 1962-1987 or in shorter bursts. As a result of the heat removal, the initial mixed layer is $1200 \mathrm{~m}$ deep (figure 3b).

After 25 years of removing a net evaporation of $10 \mathrm{~cm} \cdot \mathrm{yr}^{-1}$, the model mixed layer has reached $1950 \mathrm{~m}$ depth and its salinity is up to 38.99 . Temperature is of course well mixed down to $1950 \mathrm{~m}$ as well. Since we have not accounted for seasonal changes in heat and freshwater fluxes and the accompanying changes in seasonal stratification, these profiles are intended to represent the conditions in late-winter, nominally March 1987. For comparison, the September 1987 conditions observed by Meteor are stratified by temperature in the upper waters as expected for a late summer profile, but show little salinity variation below the uppermost $50 \mathrm{~m}$ (figure 2b). In September 1987, the depth-averaged salinity is 38.95 , fully 0.05 saltier than the March 1962 profile (table d). Much of the temperature stratification in the September profiles may be accounted for by the warming between March and September in 1987 which amounts to $2.0 \times 10^{9} \mathrm{~J} \cdot \mathrm{m}^{-2}$ according to the SOC climatology. We estimate that the September profile has a heat content of $2.65 \times 10^{9} \mathrm{~J} \cdot \mathrm{m}^{-2}$ with reference to the observed bottom temperature so that $75 \%$ of the observed thermal stratification may be due to seasonal warming from March to September.

With the model conditions after 25 years of removing $10 \mathrm{~cm} \cdot \mathrm{yr}^{-1}$ net evaporation, we continue to run the mixed layer model in monthly time steps using monthly values of $\mathrm{e}-\mathrm{p}$ and air-sea heat exchange (solar radiation minus long-wave back radiation minus sensible heat minus latent heat) from the SOC climatology from March 1987 to December 1995. Because there can be local biases in the heat and water exchanges within the SOC climatology Uosey et al. 1999) and because our premise is that long-term average heat and water exchanges are accounted for by the pre-existing circulation, we removed the 16-year average (1980-1995) heat exchange of $13 \mathrm{~W} \cdot \mathrm{m}^{-2}$ and $\mathrm{e}-\mathrm{p}$ of $101 \mathrm{~cm} \cdot \mathrm{yr}^{-1}$ from the monthly values so that the model is driven by anomalies in heat and water exchanges reflecting the local climate variability over the Aegean. In addition we continue to remove a net evaporation at a rate of $10 \mathrm{~cm} \cdot \mathrm{yr}^{-1}\left(0.83 \mathrm{~cm} \cdot \mathrm{month}^{-1}\right)$ in order to simulate the effects of river diversion in the eastern basin. The effects of the heat and water exchanges are introduced into the top $20 \mathrm{~m}$ and potential tempera-

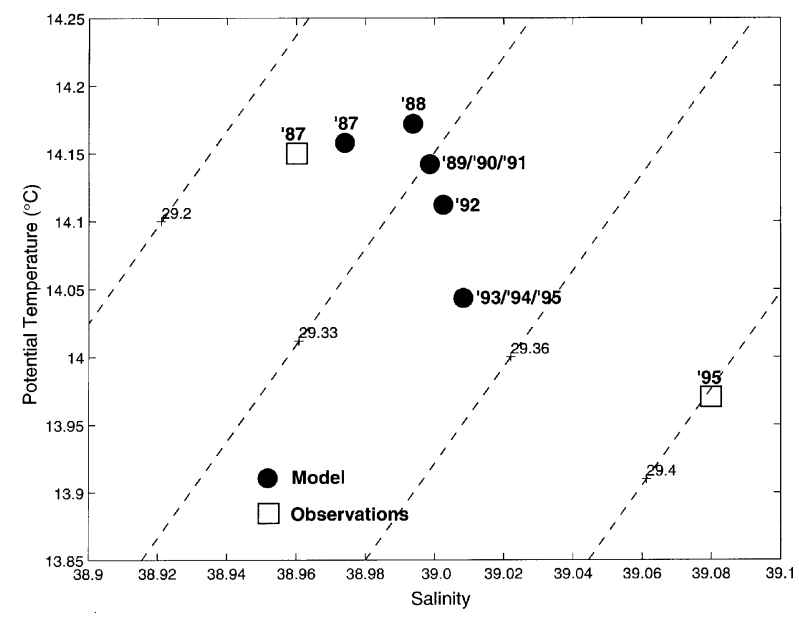

Figure 4. Aegean deep water characteristics from observations in 1987 and 1995 (open squares) and model late-winter simulations for each year from 1987 to 1995 (solid circle).

ture and salinity are then mixed downward until the profile is stably stratified. We examine the deep water properties each year at the end of March.

Within the model, deep convection had reached $1950 \mathrm{~m}$ depth in March 1987. By March 1988, the entire water column is mixed with a bottom salinity of 38.99 . New, slightly saltier deep water is again formed in March 1989, but then no new bottom water is formed through March 1991. After the winters of 1991-1992 and 1992-1993 when large wintertime heat and freshwater losses occur over the Aegean, the deep water becomes colder as well as saltier. As a result of mild conditions in 1993 and 1994, no new deep water is found in March 1994 or in March 1995 (Ggure 4). By 1995, the deep water in the model has a salinity of 39.01 and a potential temperature of $14.05^{\circ} \mathrm{C}$. The model deep water has cooled by $0.11^{\circ} \mathrm{C}$ and become saltier by 0.04 over the 8 years from 1987 to 1995 . The observed deep water salinity and temperature differences between 1987 and 1995 are higher than the values predicted by the model. This discrepancy is probably due to the one-dimensional model approach where lateral mixing and advection processes involved in the deep water formation mechanisms are ignored. However the time evolution of the simulated deep water temperature and salinity from 1987 to 1995 indicates at yearly steps the possible evolution of the deep water mass transformation from the observed value in 1987 to the subsequent observed value in 1995 (figure 4). 


\section{RESULTS}

The model shows how persistent long-term changes in net evaporation can slowly change the stratification in the Aegean basin until suddenly deep water formation occurs during a severe winter. We attribute the observed increase in depth-averaged salinity from 1961-1962 to 1987 to the increase in net evaporation following river diversion for irrigation in Russia and Egypt. That salinity increase appears as the erosion of low salinity TMW, that is by an increase in the intermediate water salinity so that TMW is effectively absent by 1987 . During the moderately cold winter of 1987-1988, new deep water may well have been formed, as suggested by Theocharis et al. (1999b) The bulk of new deep water, however was likely formed during the severe winters of 1992 and 1993. The wintertime heat loss was so great during those winters (foure 5 ) that a deep, well-mixed water column would cool by nearly $0.1{ }^{\circ} \mathrm{C}$ over the winter and the resulting new deep water in addition to being saltier would also be colder. Such cooling and salinification are both attributes of the new deep water observed in 1995 by Reether et al (1996) as compared with the deep water properties in 1987. Succeeding mild winters in 1994 and 1995 cannot form new deep water because the wintertime buoyancy loss is insufficient to overcome the surface stratification built up over the summer even though the slow increase in salinity continues due to the net evaporation.

Once a mixed layer of cold, salty dense water forms in the Aegean, it would begin to flow out over the sills connecting the Aegean to the eastern Mediterranean basin throughout the year. As the dense water slumps in the interior, lower density water must come into the Aegean to replace it. Apparently the replacement waters have a component of the low salinity TMW, for the observed profiles in January 1995 show that TMW once again separates the deep and upper waters. The presence of TMW effectively stops any further wintertime deep water formation until the low salinity intermediate waters are eroded away. There has been little research on the origin of TMW but we suspect it must come from the region east of the Aegean sea.

\section{DISCUSSION}

Estimates of the net freshwater input to the Black sea and via the Bosphorus-Dardanelles to the northern Aegean
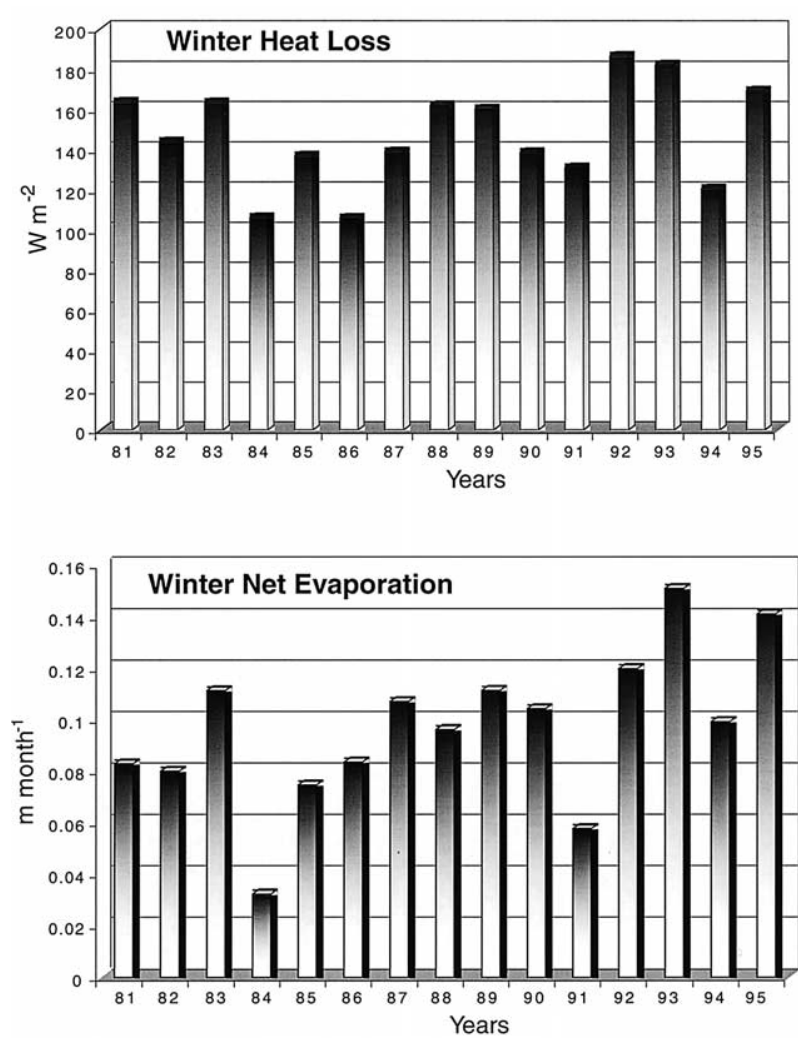

Figure 5. Winter heat loss $\left(\mathrm{W} \cdot \mathrm{m}^{-2}\right)$ and net evaporation $\left(\mathrm{mm} \cdot \mathrm{month}^{-1}\right)$ in the Aegean sea from 1980 to 1995 derived from the SOC Climatology. Averages are made for each winter period (November, December, January, February) and plotted against the year in which February occurred.

sea have ranged from 116 to $300 \mathrm{~km}^{3} \cdot \mathrm{yr}^{-1}$ and there is no apparent trend in the size of the input with the date of the estimate (Ünliiata et al. 1990). At the southern boundary of the Aegean, there is almost no signature of the freshwaters exiting the Dardanelles Rohinson et al 1979) suggesting that the net evaporation over the Aegean is sufficient to balance the freshwater input to the Black sea. A net evaporation, E, of $1 \mathrm{~m} \cdot \mathrm{yr}^{-1}$ over the $1.7 \times 10^{11}-\mathrm{m}^{2}$ surface area of the Aegean would exactly balance a freshwater input of $170 \mathrm{~km}^{3} \cdot \mathrm{yr}^{-1}$, well within the range of available estimates. Tolmazin (1985) reported that river diversion projects in Russia have reduced the freshwater input to the Black sea by 50 to $70 \mathrm{~km}^{3} \cdot \mathrm{yr}^{-1}$. Such a drastic reduction would not immediately reduce the freshwater input to the northern Aegean proportionally as we would expect that the Black sea salinity should gradually increase with time and that the Bosphorus-Dardanelles exchange should slowly decrease 
with time but remain proportional to the density (or salinity) difference between the Aegean and Black seas. For the model, we assume a constant reduction in the freshwater input to the Aegean of $10 \mathrm{~cm} \cdot \mathrm{yr}^{-1}$, or about $10 \%$ of the net evaporation. Such a change in E for the Aegean could appear either as a $10 \%$ decrease in the flow from the Dardanelles into the Aegean, or as an increase of about 1 (from 29 to 30) in the salinity of the Black Sea waters exiting the Dardanelles, or as a combination. In fact, Zervakis et al (2000) presented evidence for a substantial reduction in the Dardanelles outflow from 1981 to 1994.

Lascaratos et al_(1999) reviewed the different mechanisms put forward for the formation of new deep waters in the Aegean sea between 1987 and 1995. While mentioning the reduction in river discharge, they identified meteorological anomalies (cold winters) between 1987 and 1993 as the likely cause. Wu et al_(2000) used a three-dimensional numerical model of Mediterranean circulation to show that imposing large wintertime heat losses over the northern Aegean leads to the formation of cold, dense waters in the north which then mix with salty Levantine Intermediate Water to form new cold salty deep waters in the Aegean. They too noted changes in net evaporation but these are apparently only side effects of the cold wintertime forcing they impose. Theocharis et al $1999 \mathrm{~b}$ also noted the trends in net evaporation due to river diversion but concluded that low precipitation during 1989-1993 is the fundamental cause of the new salty deep water in the Aegean. Examining observations near Crete, Georgopoulos et al (2000) found lenses of salty water on the continental slope which they argued may lead to the formation of Aegean deep water by a process of eddy ventilation. From time series of hydrographic properties in the basins of the north Aegean, Zervakis et_al_(2000) nearly concluded that changes in net evaporation due to Russian river diversion have led to new denser deep waters in the northern basins, but then cautioned that sea level in the Black Sea has been rising recently which suggested that more, not less freshwater is leaving the Black Sea and entering the Aegean.

Nearly all analyses have concentrated on the formation of new Aegean deep waters over the time period from 1987 to 1995 using 1987 observations as the baseline from which new deep waters are formed. We are in basic agreement with these analyses that new deep waters were actually formed during cold wintertime conditions, probably during the winters of 1991-1992 and 1992-1993 when there were large heat and freshwater losses over the Aegean (figure 5). In this work, however, we stress the change in net evaporation due to Russian river diversions as the cause for the slow erosion of the low salinity intermediate waters from 1962 to 1987, which ultimately created the conditions suitable for deep water formation during severe winters. The formation of new deep waters in the Aegean is a result of the two processes: a long, slow increase in the salinity due to changes in the water budget and then a catastrophic deep water formation event during a harsh cold, dry winter. While we have concentrated on local, one-dimensional arguments for simplicity, we accept the limitations of our approach where the horizontal advection and mixing contributions are not taken into account. Whatever are the contributions of those factors, we believe that they do not obviate the main result outlined here.

The presence of low salinity intermediate waters in 1995 while the recently formed deep waters are still flowing out of the Aegean over the sills into the deep eastern Mediterranean (Theocharis et al, 1999b) strongly suggests that deep water will not be formed again for several years in the Aegean. Erosion of the imported low salinity TMW will be necessary before wintertime deep water formation can occur again. While it is tempting to suggest that deep water will not be formed for 25 more years until the effective extra net evaporation due to river diversion erodes the intermediate water salinity minimum and preconditions the Aegean sea to deep water formation, the overall circulation in the eastern Mediterranean and Aegean may have changed as a result of the Aegean deep water formation and subsequent outflow over the sills or the effects of river diversion may have a positive feedback with time. Predictions are perilous. It is interesting, however, to note that a basin like the Mediterranean does not become uniformly saltier over time following a change in its water budget. On the basis of observations and understanding to date, it appears that salinity initially increases near to where the water balance has changed; salty deep water is then formed in a local deep basin which then spills out over the sills spreading into the greater deep basin; within the local basin the outflowing dense waters are replaced by lower salinity waters which then shut off deep water formation. The cycle may repeat: we eagerly await new observations of the next stage as the Mediterranean becomes saltier and new model simulations brave enough to predict what will happen next. 


\section{Acknowledgements}

The authors thank Dr B. Klein and Prof. W. Roether for making available the CTD data in the Aegean sea from Meteor cruises in 1987 and 1995. Dr S. Josey was very helpful in accessing the SOC Climatology data. The first author would like to thank Dr W.J. Gould, Director of Woce and Clivar International Project Offices, for encouraging her to do this analysis in addition to her Woce and Clivar duties. Initial analysis was stimulated by Prof. Roether's presentation at a Clivamp meeting in March 1996. This work has been carried out as part of the James Rennell Division's research programme 'Observing and modelling seasonal to decadal change in the ocean' which is primarily supported by the Natural Environmental Research Council.

\section{REFERENCES}

Bethoux, J.P., 1980. Mean water fluxes across sections in the Mediterranean Sea, evaluated on the basis of water and salt budgets and of observed salinities. Oceanol. Acta 3, 79-88.

Bruce, J.G. Jr, Charnock, H., 1965. Studies of winter sinking of cold water in the Aegean Sea. Extrait des rapports et procès-verbaux des réunions de la CIESM XVIII, 773-778.

Georgopoulos, D., Chronis, G., Zervakis, V., Lykousis, V., Poulos, S., Iona, A., 2000. Hydrology and circulation in the southern Cretan Sea during CINCS experiment. Prog. Oceanogr. 46, 89-112.

Josey, S.A., Kent, E.C., Taylor, P.K., 1999. New insights into the ocean heat budget closure problem from analysis of the SOC air-sea flux climatology. J. Climate 12, 2856-2880.

Klein, B., Roether, W., Manca, B.B., Bregant, D., Beitzel, V., Kovacevic, V., Luchetta, A., 1999. The large deep water transient in the Eastern Mediterranean. Deep-Sea Res. 46, 371-414.

Lacombe, H., Tchernia, P., Gamberoni, L., 1984. Variable bottom water in the western Mediterranean basin. Prog. Oceanogr. 14, 319-338.

Lascaratos, A., Roether, W., Nittis, Klein, B., 1999. Recent changes in deep water formation and spreading in the eastern Mediterranean Sea: a review. Prog. Oceanogr. 44, 5-36.

Leaman, K.D., Schott, F.A., 1991. Hydrographic structure of the convection regime in the Gulf of Lions: Winter. J. Phys. Oceanogr. 21, 575-598.
Miller, A.R., 1974. Deep convection in the Aegean Sea. Colloques internationaux du CNRS 215, 155-163.

Miller, A.R., Tchernia, P., Charnock, H., McGill, D.A., 1970. Mediterranean Sea Atlas. Woods Hole Oceanographic Institution Atlas Series, vol. 3.

Nielsen, J.N., 1912. Hydrography of the Mediterranean and adjacent waters, Report of the Danish Oceanographic Expedition 1908-1910 to the Mediterranean and Adjacent Waters, vol. 1, pp. 72-191.

Pollack, M.J., 1951. The sources of the deep water of the eastern Mediterranean Sea. J. Mar. Res. 10, 128-152.

Robinson, M.K., Bauer, R.A., Schroeder, E.H., 1979. Atlas of North Atlantic-Indian Ocean Monthly Mean Temperatures and Mean Salinities of the Surface Layer. Naval Oceanographic Office, Bay St. Louis, Miss.

Roether, W., Schlizter, R., 1991. Eastern Mediterranean deep water renewal on the basis of CFC and tritium data. Dyn. Atmos. Oceans 15, 333-354.

Roether, W., Manca, B.B., Klein, B., Bregant, D., Georgopoulos, D., Beitzel, V., Kovacevic, V., Luchetta, A., 1996. Recent changes in eastern Mediterranean deep waters. Science 271, 333-335.

Rohling, E.J., Bryden, H.L., 1992. Man-induced salinity and temperature increases in western Mediterranean deep water. J. Geophys. Res. 97, 11191-11198.

Theocharis, A., Balopoulos, E., Kioroglou, S., Kontoyiannis, H., Iona, A., 1999. A synthesis of the circulation and hydrography of the South Aegean sea and the straits of the Cretan Arc. Prog. Oceanogr. 44, 469-509.

Theocharis, A., Nittis, K., Kontoyiannis, H., Papageorgiou, E., Balopoulos, E., 1999. Climatic changes in the Aegean Sea influence the Eastern Mediterranean thermohaline circulation. Geophys. Res. Lett. 26, 1617-1620.

Tolmazin, D., 1985. Changing coastal oceanography of the Black Sea, I. Northwestern shelf. Prog. Oceanogr. 15, 217-276.

Ünlüata, Ü, Oguz, T., Latif, M.A., Özsoy, E., 1990. On the physical oceanography of the Turkish straits. In: Pratt, L.J. (Ed.), The Physical Oceanography of Sea Straits. Kluwer, London, pp. 25-60.

Wu, P., Haines, K., Pinardi, N., 2000. Toward an understanding of deep-water renewal in the Eastern Mediterranean. J. Phys. Oceanogr. 30, 443-458.

Zervakis, V., Georgopoulos, D., Drakopoulos, P.G., 2000. The role of the North Aegean in triggering the recent Eastern Mediterranean climatic changes. J. Geophys. Res. 105, 26103-26116. 